\title{
The Verbo -Nominal Structures in German and Yorùbá Languages: Parallels and Contrasts
}

\author{
Deborah Adeyeye ${ }^{1}$, Ogunwale Abiodun ${ }^{2 *}$ \\ ${ }^{I}$ Department of Foreign Languages, University of Benin \\ ${ }^{2}$ Department of Linguistics and African Languages, Obafemi Awolowo University, Ile-Ife, Nigeria
}

*Corresponding Author: Ogunwale Abiodun, Department of Linguistics and African Languages, Obafemi Awolowo University, Ile-Ife, Nigeria

\begin{abstract}
The morpho-syntatic analyses of lexical structures of complex verbs in German and Yorùbá languages are the thrusts of this study. The study primarily identifies German complex verbs found in Blechtrommel's Gunter Grass and Yorùbá complex verbs in Igbó Olódùmarè -a literary text of Fagunwa, as data base. Secondaryly, the morpho-syntax of the identified corpus in the two languages and their categorizations are highlighted with a view to pragmatically synthesising, comparing and contrasting the contextual usages which the corpus exhibited. As a a framework, the Contrastive Analysis Theory of Robert Lado is adopted. The result showes that some of the complex verbs in both languages comprised of two or more constituents; while those having more than two constituents are in the minority. As a result of the composite nature of the verb forms in the languages coupled with other identified idiosncracies, remarkable features of distinction noticeably distinguish the morphology and pragmatics of verb-forms in the two languages,especially when prepositional or nominal items are concatenated with verb-forms.Conclusively therefore, it is opined that the preceding deserning factors are substantial and capable of instantiating areas of learning difficulties for Yorùbá learners of German and German learners of Yorùbá languages pedagogically.
\end{abstract}

Keywords: complex verbs, composite words, decomposition, derivation, morphology, syntax

\section{INTRODUCTION}

Although German and Yorùbá languages belong to two different world language- groups, but there exists a number of individuals who are faced with the challenge of having to combine the knowledge of the two languages either as bilingual individuals or for heuristic reasons in this modern world. In any of such circumstances, confusion emanating from the composition and the inalienability of the constituents of complex verb- formation can hardly be ignored. This is particularly so when it comes to abstracting the lexical status in order to effect the semantic value of complex verbs in either of the two languages. It is also found that there are a number of instances where verb forms in the two languages typically contain more than one morpheme within a verb- constituent, thereby making the notion of wordhood of a verb in the two languages to be quite intriguing. Thus, plethora of studies abound in the two languages where scholars have independently ventured to expound the status and the morphological structures of words, as opposed to syntactic structures, in the contexts of their syntactic and pragmatic configurations. ${ }^{1}$

For example Adewole (1997:4) proposes that syntactic categories are defined according to whether they analyze complete or incomplete expressions while the domain of verbal process is determined by the instantiation of the feature, [LEXICAL]. For words like a verb, however, lexicality is fixed and defines the domain of lexical rather than syntactic processes. In other words, words in morphology is taken as primitive and defined as X[+LEX ] which means a lexical category that is neither a stem or an affix. In Generalized Phrase Structure Grammar( GPSG)analyses which he uses, we are made to understand that, a lexical category is neither a stem nor an affix. The lexical features appear with their own lexical entries, which means that they do appear through the operation of the word formation rules. Verb forms, are lexical categories and they are defined parallel to syntax with the use of two single value feature denoting [+word] (i.e non-stem and non- affix). The lexical features instantiated above connotes that they can appear through the operation of the word formation rules. 
Further highlights on word is however given .by Miller, cited in Sprout (1994:234), that complex verbs as verbs that have undergone derivational processes in order to modify the form, augment the meaning and spur the structures of arguments of the base- verb ${ }^{2}$. In addition, Mathew in Ogunwale (2005:318ff), and Ogunwale(2012:123ff) and (2015:79ff),in another independent study, expatiate what could be taken as a morphologically complex word in Yorùbá .It is opined in the studies that a root cannot be broken into smaller grammatical units but word-forms could be derived by the addition of other morpheme(s) and affix(es).The descriptions of Miller and Mathew observably point to the fact that a complex verb is formed by the addition of other morphological constituents which could either be free or be bound to a verb. Such a co- constituent may or may not share the same lexical category with the (root) verb. The attempt of the present study, however, is to provoke further discussions by highlighting the constituents in verb-forms in the area of contrastive linguistics drawing corpus from German and Yorùbá languages.

\section{Statement of Problem}

Complex verbs in both German and Yorùbá, as the name implies, are not without complexities for linguists to decompose because the internal constituents of complex verbs in the two languages are enigmatic and problematic.As a result, it is observed that the morpho-syntatic behaviours of the word-forms in the two languages call for a systematic account and delineation. The problems in such account stem from the fact that there is the primary need to systematically describe complex verbs, noun formation processes and nominal compound formation in the two languages with a view to assisting the bilingual students working on the two languages. A focus of this study therefore would be a detailed illustration of the morphological structures within the contexts of similarities and dissimilarities of complex verbs in German and Yorùbá languages. These shall be taken up one after the other in the course of this study.

\section{Data Base}

The data to be analysed in this study are those German complex verbs selected from Blechtrommel's Gunter Grass and the Yorùbá complex verbs garnered from the Yorùbá Igbó Olódùmarè.The texts are taken because they are deemed to be representatives of the synchronic usage of the languages.

At this juncture, it behoves us to provide further justification for our choice of the texts- (both Blechtrommel and Igbó Olódùmarè) .This is because we assume not every reader could be familier with the texts and secondly we want to free our choice of corpus from mere intuition. The choice of the two texts are neither randome nor amorphous,rather they are deliberately chosen in recognition of the fact that the authors are good users of the lanaguages who exploit the language intuitions of the native speakers expressively and independently derive complex verb- forms found in those texts. Now, we take the texts in turn:

\subsection{Blechtrommel by Gunter Grass}

(You will do what I do for Igbó Olódùmarè below (see 3.2) for the text in German mentioned above because not every prospective reader is familier with the texts and the author. We need to do so in order to free our choice from intuition and mere marriage of covenience. We may however decide to shift it to 3.1 and 3.2 , or be given as the appendix or be shifted to the end-notes.But I will however prefer it to be situated at this column)

\subsection{The Fagunwa Igbó Olódùmarè}

D.O Fagunwa is a reknown Yorùbá literary icon who was able to create a niche for himself in the way he demonstrated unequal amount of literary wizardry against the backdrops of Yorùbá tradition and people`s folktales. The novel Igbó Olódùmarè is one of the five novels authored by Fagunwa in his life time. Igbó Olódùmarè was published in 1949,although it has repeatedly been published till date. Fagunwa was not only a pioneer of creative writings in Yorùbá,but he was also adjudged to be a foremost novelist in the language.

The novel is replete of composite words where we find :

- roots and words formed from the language and its dialects

- words which cannot be traced to roots and the meanings of which cannot be derived by putting together the meanings of their component parts 
- words acquired from foreign languages but syntatically used as a verb form.

The present study is not a literary studies of a text. As a result, we shall not delve into the literary content nor the synopses of Igbó Olódùmarè.Rather,we are fascinated to the text by how the book is able to knit up morphemes ,configure new words, innovate the existing words to yield new meanings ,establish new meaning from a configured word ,etc.We consider these to be a feat that are only possible in the hands of a word-smith to which the author of Igbó Olódùmarè could conveniently lay claim. And as it were,they are good materials for morphological exposition.

\section{COMPLEX VERBS IN GERMAN AND YORÙBÁ LANGUAGES}

This chapter analyses the the ccomplex verbs found in both German and Yorùbá languages ,starting from the data from German .

\subsection{German Complex Verbs}

Below are the tokens of verbs that are analysed in this study.The rationale for grouping them will become manifested as we go further in the discussion.
$\{1\}$ (a) (i) erschienen
(ii) erblicken
(iii) versammeln
(iv) entdecken
(b) (i) beantragen
(ii) beeindrucken
(iii) veranlassen
$\{2\}$ (a) (i) abraten
(ii) aussprechen
(iii) auffallen
(iv) nachlesen
(v) mitbekommen
(b) (i) hervorziehen
(ii) voraussetzten
(iii) zusammenlesen
(iv) zurücktreiben
$\begin{array}{ll}\text { (c) } & \text { (i) kennenlernen } \\ & \text { (ii) spazierengehen }\end{array}$
(d) (i) festhalten
(ii) fernbleiben
(iii) fortführen
(iv) freimachen
(e) (ii) handhaben

\subsection{Yorùbá Complex Verbs}

[3]
(a) (i) gbàdúrà
(ii) borí
(iii) gbádùn
(iv) gbéyàwó 

(v) kọrin
(vi) rántí
(b) (i) fàya
(ii) fàya
(iii) pàdé
(iv) rẹ́jẹ
(v) pajẹ
(C) (i) yẹ́sí
(ii) rẹ̀sílẹ̣
(iii) bẹ̀rẹ̀sí

The data presented in 4.1 and 4.2 above cannot be said to be an exhaustive lists of complex verbs in the languages of our discussion, rather could only be taken as mere representative of complex verbs garnered from the above named literary works. Their grouping is attempted to facilitate easy discussion and analysis.

\subsection{Analyses of Data}

The present sub-section engages in the systematic discussion of the data presented above as coming from the German language first,and according to the category into which they are classified:

\subsubsection{Complex Verbs in German}

Steinbach et al (2007:59): ${ }^{1}$ and Altmann/Kemmerling ${ }^{1}$ (Steina...) grouped the German complex verb formation into four: Prefixed verbs (Präfixverbe.gzerfallen), particle-prefixed verb (Partikelpräfixverbe.gumfahren), particle verb (Partikelverbe.gumfahren) and double-particle (Doppelpartikel-verb e.ghineinlaufen).These have been given earlier but repeated as [4] for emphasis:

\section{[4] (i)}

However, it is found that there exists only two that are outstanding among them. These major types are:

(a) those that are morphologically and syntactically inseparable i.e. prefixed verbs (Präfixverben), and

(b) those that are both morphologically and syntactically separable i.e. particle verbs (Partikelverben). These are briefly illustrated below:

(where are the first category identified in (a)as prefix verbs? Illustrate them here and give them identification number as appropriate) situate them as [5] below [5]

- Particle Verbs

Dehe (2015: 613) in his study attests to the German particle verbs as

... (also: phrasal verbs, separable (complex) verbs, verb-particle combinations) are combinations of verbs and preposition like elements.

Particle verbs are a type of complex verbs which can broadly be subdivided into two constituents either morphologically or syntactically. Furthermore, according to Duden Grammatik and Müller, particle verbs are complex verbs with morphological and syntactical first constituent. The analyses of the first constituents of particle verbs have earlier been undertaken by different researchers, for example, Fleischer (20??????), calls it prefix (Präfix). Wellman( 200?????) referred to them as halfprefix (Halbpräfix), they are referred to as postponed pre-verb (postponierbares Präverb) by Simeckova and as verb particle (Verbpartikeln) by Eichinger and Eisenberg. In syntax, the first 
constituent of particle verbs is referred to as verb ancillary (Verbzusatz). Lüdeling describes three positions of particle verbs in German which include:

- Particle verbs are separable complex verbs with pre-verb, these pre-verbs like spazieren(to stroll) in spazierengehen (to walk)belong to arbitrary syntactic category.

- Particles of the Particle verbs are mostly intransitive prepositions that require both syntactic analysis and also morphological analysis.

- The third group of particles include those that are formed with adverbs, adjectives and/or prepositions e.gab, auf, nach, unter, wider, fest, frei.

Examples of particle verbs in German include:

[6] einsammeln (to collect), einkehren (to come), freikaufen (to ransom), nachziehen (to trail,to follow), mitspielen (to play with).

\section{- Prefixed Verbs in German}

Generally, prefixes are bound morphemes that are placed at the left side of the (root) verb.German verbs are monosyllabic with abstract meaning. Prefixed verbs under explicit derivation are described as complex verbs with inseparable derivational prefixes. Prefix verbs are referred to in German grammar books as pure prefixes (echten Präfixen), verbal prefixes derivative (verbale Präfixderivate).These groups of complex verbs are neither morphologically nor syntactically inseparable ${ }^{1}$.Verbal prefixes in German are grouped into two; prefix without homonym verb particle such as:

be-, ent-, ge-, miss-,ver-, zer-and prefix with homonym verb particle such as

durch-, hinter-, über-, um-, unter-, wider.

Particle verbs are differenciated from prefix verbs in that prefix verbs cannot be separated when the verb appear at the position of a sentence, and the stress of the particle verb is on the particle, i.e prefixed verbs have their stress on the basic verb ${ }^{1}$. Examples of prefixed verbs are:

[8] bedecken (to cloak,to cover), bedürfen(require), begehren (desire) entgehen (to avoid), erblicken (to behold)

\subsubsection{Complex Verbs in Yorùbá}

Verbs in Yorùbá are majorly monosyllabic, although there are sizeable number of them that are derived with more than one syllable/morpheme.Ogunwale (2007:79) identifies the Yorùbá prefixes as been heads of their respective tokens. Head words in Yorùbá are analoguous of head in syntax where the head words are capable of changing the categorial status of lexical words in the grammar of the language. [9] can be cited as example in this regard:

$\begin{array}{llll}\text { prefix } & + & \text { verb -------> } & \text { noun } \\ \text { a } & + & \text { bọ̀ (arrive) } \mathrm{v} & \text { àbọ̀( arrival) } \\ \text { ọ (Prefix) } & + & \text { gbọ́n (to be wise)v } & \text { ogbọ́n(wisdom)N }\end{array}$

Observably,it is found that it is the prefix $/ \mathrm{o} /$ that changes the verb form from a verb to a noun.

Yorùbá verbs accordimg to Awoyale in Ògúnwálé (2005:319) ${ }^{1}$, therefore,are canonically monosyllabic roots with regards to complex verb formation. Asiwaju (1967: 32ff) ${ }^{2}$ also pointed out that Yorùbá verbs have verbal combinations which can be likened to the German verbalcompositon as found in :

[10] (toju- sorgen, yawo- Geld borgen, kawe-lesen, logbe- abholen).

The structure of Yorùbá complex verbs are usually difficult to determine for a non linguist because of the unpredictability associated with the categorization of verbs in the language. At least for two major reasons: (i) Homonymic conflicts as a result of a word encapsulating more than a single meaning. Words do swoop meanings and meanings do swoop words such that each of them could entail overlapping values.

(ii) The issue of word bundary erazure may make the exact deleted phoneme to be difficult to discern,especially when the word final of the verb (in the first word) is a vowel and the word initial in 
the second word is alsoa vowel.One finds it difficult to know what and which vowel is deleted from either the verbal or the nominal items following a contraction process. Confusions therefore arises when it comes to the assignment of a particular meaning to the contracted word.Although there are disambiguation mechanisms in the language that help in such language difficulty.(Ogunwale,1997: 99)

Let us quickly examine the issue of homonymic conflict in [11]

[11] (i) pakú - do it in such a way that it will die

patì-do it in such a way that it will become abandoned

parí-do it in such a way that it will get to the end

parun-do it to effect destruction

pajẹ-do it to make it be edible

(ii) kọjú- to face (a certain direction)

kọrí-to turn

kọlà-to inscribe tribal marks

kọlóminú-to baffle one

(iii) dásí-to intervain

dákú- to covurse

dágbé- to live a solitary life

dásùn - to sleep lonely

dájí - to wake up all alone/in the midnight

A more comprehensive work on instances of Yorùbá mono-syllabic verbs is contained in Adewole (1997) where he catalogues samples of Awóbùlúyì (2008: 127-187) which classified verbs in Yorùbá into thirteen different classes which include amongst others: splitting verbs, complex verbs, echoing verbs and adjectivisable verbs,etc. He posits that a group of Yorùbá complex verbs have idiomatic meanings and as such, have newer entries in the lexicon. Awóbùlúyì (2008:208ff) noted that that there is absence of derivational affix in the formation of complex verbs in Yorùbá unlike what obtains in German language. He also stated that complex verbs are morphologically formed with a verb and its object.The two elements he referred to as verb phrase (Àpólà-ịse).These are illustrated in [12] below:

[12] (i) gbọ (hear)+ afẹe (enjoyment) $\rightarrow$ gbáfẹ (to enjoy).

It will be noted that [12](ii) below is differently formed by combining two verbs :

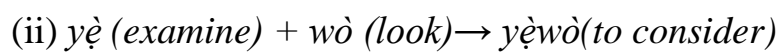

Another category of Yorùbá composite verbal elements found are formed by combining a verb and a preposition as found in :

(iii) bọ́ (fall)+sí (in ) $\rightarrow$ bọsí (to succeed).

He noted that out of the three processes of deriving a complex verb in Yorùbá, the most productive is the verb and noun process. The Awobuluyi, Taiwo, Ogunwale, Asiwaju and Madugu observations that have been alluded to above, are almost similar in form and content.

\subsection{Analysis of Corpus from the Texts}

The above listed data in section 3 exihibit certain attributes which are germane to the morphological and syntactical analysis of complex verbs in both German and Yorùbá. In this section however, the morpho-syntactic features of each group would be discussed with each having its heading.

\subsubsection{Decomposition of German Prefix Verbs:The Gunter Grass Examples}

All items in one (1a ) and (1b) are prefixed verbs. Prefix are monosyllabic bounded morphemes joined to a word or verb. Verbal prefixes have abstract meaning as opposed to other monosyllabic 
morphemes. Prefix verbs are both morphologically and syntactically inseparable. For example, complex verb in (1a) are morphologically and syntactically illustrated below as [13] for convinience

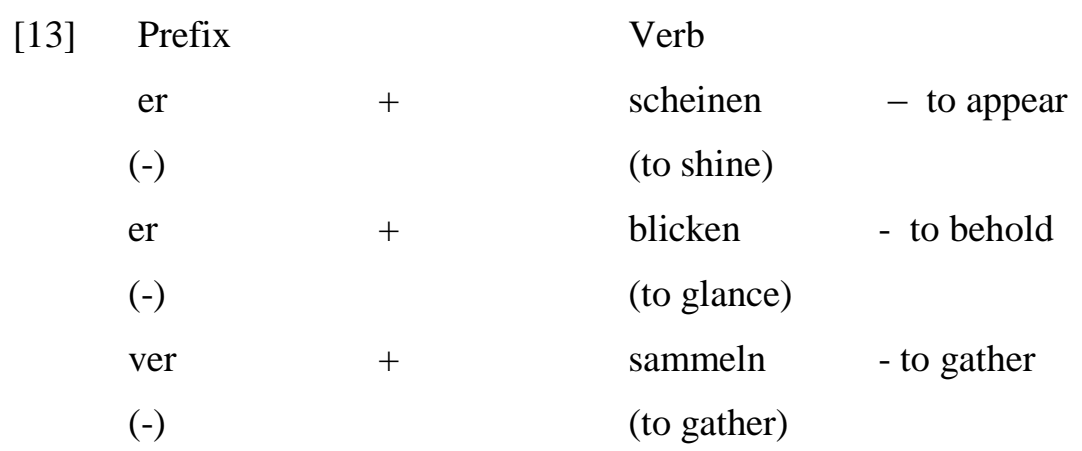

Examples of prefix verbs are illustrated in German sentences below:

(i) Er wollte mir wie ein von ein Gedanken bewegter Bruno erscheinen

(He wanted to appear to me as a Bruno moved by thoughts)

(ii)Wenn sie sich setzte, versammelt sie ihre Röcke um sich

(When she sat down, she gathered her skirt around her)

(iii)Wranka erblickt in Tuchel das Licht dieser Welt.

(Wranka see the light of this world in tuchel)

All items of verbs in (1b) are repeated as (5) below. These sets of complex verbs are also categorise as prefixed verbs though they with a different morphological constituent from the ones in number (4). As illustrated in [14] below, these class of prefix verbs take both inseparable prefix and separable verbal particle but with the inseparable prefix appearing first.

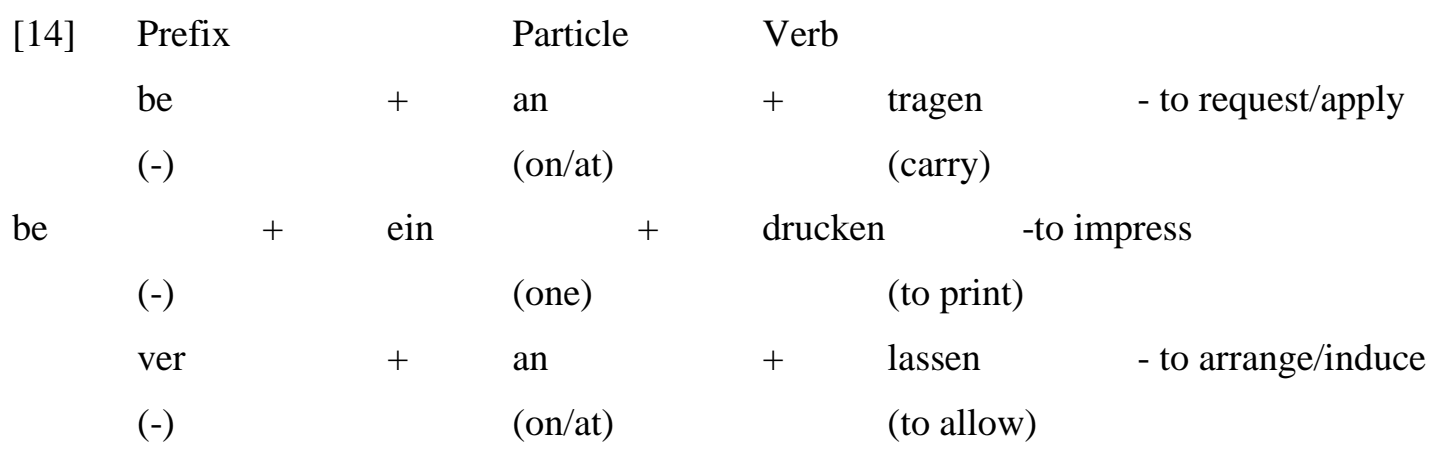

Prefix verbs in German are sometimes referred to as inseparable complex verbs. In zu infinitive sentences, $z u$ - preceeds the prefixed verbs . Prefix verbs due to their inseparability follow the parttern of simple verbs in their past tense formation.Examples are below

[15] Sie versucht ihren Rock um sich zu versammeln

(She tries to gahter her skirt around her) --zu infinitive

[16] Sie hat ihren Rock um sich versammelt

(she gathered her skirt around herself) --past tense

\subsubsection{Decomposition of German Particle Verbs}

All items of complex verbs in (2a)- (2e) are labelled as particle verbs. Particle verbs are morphologically and syntactically separable. The verbal particle of particle verbs are essentially prepositions, adjectives, verbs, adverbs and nouns. While the verb occupies the left sentence bracket, the verbal particle occupies the right sentence bracket in declarative sentences. The position of the particle changes with the sentence type or structure in German sentences.

Particle verbs with prepositional particle

Items in (2a) are repeated here for convinience 


\begin{tabular}{|c|c|c|c|}
\hline Prepositioanal particle & & Verb & \\
\hline $\mathrm{ab}$ & + & raten & -to discourage/ dissaude \\
\hline (from) & & (to advise & \\
\hline auf & + & fallen & - to stand out/notice \\
\hline (upon/at) & & (to fall) & \\
\hline aus & + & sprechen & -to express/pronounce \\
\hline (from/of) & & (to speak) & \\
\hline nach & + & lesen & - to cross-check \\
\hline (after) & & (to read) & \\
\hline
\end{tabular}

The following are sentences with particle verbs.

[18](i) Ich rate davon ab. (i advised against it)

(ii) Wir sprechen es aus (We are pronouncing it)

(iii) Meinem Großvater fielen erst hinter Daischau seine Beschatter auf (my grand father noticed his spy behind the slide show)

(iv) Der Mann liest sein Antragsformular immer nach. (The man reads his application form always)

Prepositional verb particles function as the core of verbal lexicon because they freely joined to simple verb inorder to create new verbs. $79.3 \%$ of complex verbs examined in the data are made up of prepositional verb particle.

\subsubsection{Particle Verbs with Adverbial Particle}

[19] Complex verb items in (2b) are decomposed here

Adverbial particle

hervor

(out of/from)

voraus

(ahead/to the front)

zusammen

(together)

$\begin{array}{ll} & \text { Verb } \\ + & \text { ziehen - to pull out/remove } \\ + & \text { (to pull/drag) } \\ + & \text { setzten - to require/ demand } \\ & \text { (to place/put) } \\ & \text { lesen -to read together } \\ & \text { (to read) }\end{array}$

(to create/do)

$$
+\quad \text { treiben - to repel/repluse }
$$

(back)

Adverbial verb particle are not productive in the formation of complex verbs in German and adverb of place like oben, unter, hinter (above, below, after)do not function as particles of complex verbs. $17 \%$ of complex verbs examined in the data are made up of adverbial verb particle.

Particle verbs with verbal particle.

[20] Complex verbs in (2c) are decomposed here

$\begin{array}{lll}\begin{array}{l}\text { Verb } \\ \text { kennen }\end{array} & + & \begin{array}{l}\text { Verb } \\ \text { lernen - to meet somebody } \\ \text { (to know somebody) }\end{array} \\ \text { spazieren } & & \begin{array}{l}\text { (to learn/study) } \\ \text { gehen - to stroll/walk } \\ \text { (to stroll) }\end{array} \\ \end{array}$

Particle verbs with verbal particle are considered as product of compostion as against others which areprodcut of derivational processes. They account for $0.2 \%$ of the examioned verbs for this study. 
Particle verb with adjectival paticle

[21] Items in 2 are decomposeed here

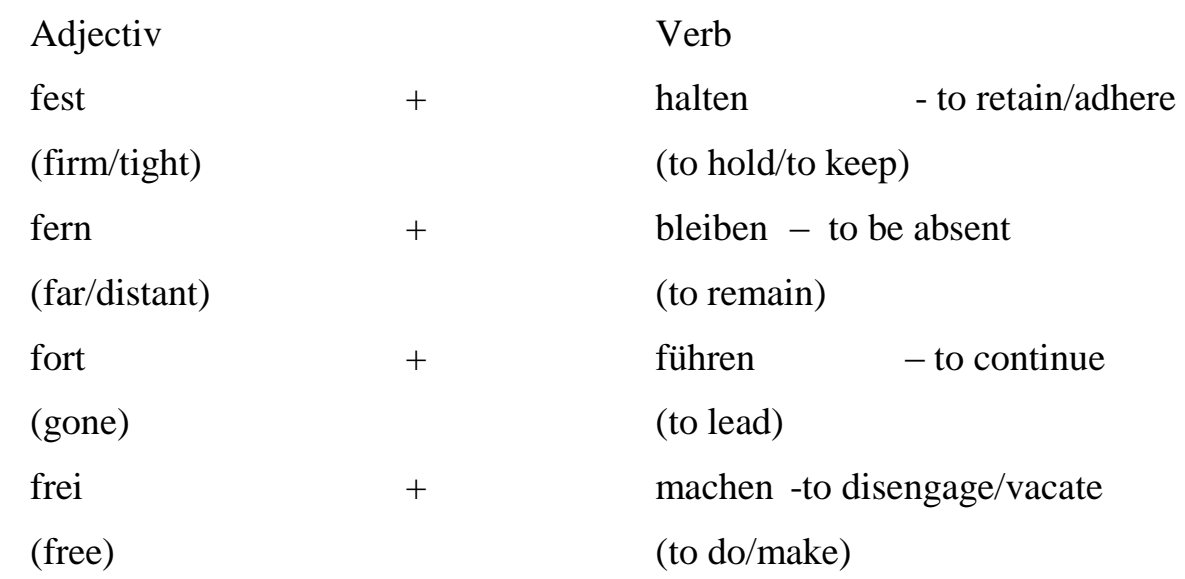

Simple adjectives like fest, fern.weiter function as verb particle as opposed to complex adjectives like $u n$, ur, miss, which do not function as verbparticle. Only $3.6 \%$ of complex verbs in this study are made up of adjectival verb particle.

Particle verb with nominal particle

$\begin{array}{ll}\text { [22] Noun } & \text { Verb } \\ \text { Hand } & +\quad \begin{array}{l}\text { haben }- \text { to administer/manage } \\ \text { (Hand) }\end{array}\end{array}$

Nominal particle are not productive in complex verb formation in German language though complex verb with nominal constituents can sometimes be derived through other morphological process like conversion e.g (Schulmeister/ lecturer- schulmeistern/ to lecture), through back formation (Schutzimpfung/vaccination- schutzimpfen/ to vaccinate). Only $0.2 \%$ of complex verb understudied were with norminal particle.

In zu-infinitive sentences, particle verbs take a zu in-between the particle and the verb. Examples are: abtrommeln $\rightarrow$ abzutrommeln, einschlagen $\rightarrow$ einzuschlagen, ausfallen $\rightarrow$ auszufallen. In addition to this, particle verbs have a -ge- added in-between the particle and its verb to form the past tense for example: abraten $\rightarrow$ abgeraten, aussprechen $\rightarrow$ ausgesprochen, auffallen $\rightarrow$ aufgefallen.

\subsection{Decomposition of Complex Verbs in Yorùbá}

Awoyale as cited in Ògúnwálé asserts that verbs in Yorùbá are majorly monosyllabic although there are some simple verbs that have more than one syllable. According to Awobuluyi, complex verbs in Yorùbá are not product of prefixation but product of composition which are most times cases of contractions. In a similar study on complex verbs in Yorùbá Asiwaju stated that the Yorùbá language verbal kombintion e.g (tọjú - to take care of, yáwó- borrow money, kàwé - read,) resembles the germaan compositional verbs. The complex verbs identified in this study would be discussed below.

Complex verbs with nominal constituent

[23] Items listed in (3a) are repeated below for decompositon

\begin{tabular}{|c|c|c|}
\hline Verbs & & Nouns \\
\hline $\begin{array}{l}\text { gbà } \\
\text { (to receive) }\end{array}$ & + & $\begin{array}{l}\text { adúrà - to pray } \\
\text { (pray) }\end{array}$ \\
\hline $\begin{array}{l}\text { gbà } \\
\text { (to receive) }\end{array}$ & + & $\begin{array}{l}\text { adùn -to enjoy } \\
\text { (sweetness) }\end{array}$ \\
\hline $\begin{array}{l}\text { gbé } \\
\text { (carry) }\end{array}$ & + & $\begin{array}{l}\text { ìyàwó - to marry } \\
\text { (bride) }\end{array}$ \\
\hline kọ & + & orin - to sing \\
\hline
\end{tabular}




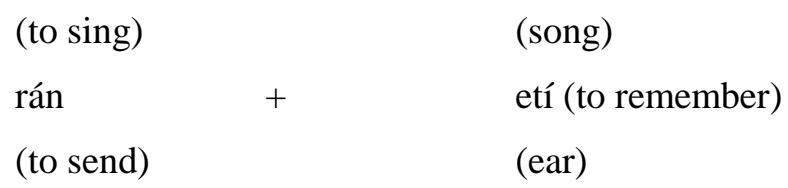

Majority of the complex verbs in this study fall under this category. Nouns are easily combined with simple verbs to form complex verbs as they are in Yorùbá. 63.7\%. The right hand verb constitutes the head- word of the token .

Complex verbs with verbal constituent.

[24] Complex verbs items in (3b) are decomposed here.

$\begin{array}{lll}\begin{array}{l}\text { Verb } \\ \text { fà }\end{array} & + & \begin{array}{l}\text { Verbs } \\ \text { ya }- \text { to rear } \\ \text { (to draw) } \\ \text { (to tear) }\end{array} \\ \text { fà } & + & \begin{array}{l}\text { yọ - to subtract/ draw out } \\ \text { (to remove) }\end{array} \\ \text { pa draw) } & & \text { dé - to close } \\ \text { (to kill) } & + & \text { (to cover) } \\ \text { ré } & \text { jẹ -to cheat } \\ \text { (to slice) } & + & \text { (to eat) } \\ \text { pa } & + & \text { jẹ - to kill animal for food } \\ \text { (to kill) } & & \text { (to eat) }\end{array}$

Complex verbs in Yorùbá are also derived by combining two verbs together. $23 \%$ of the verbs understudied are complex verbs with verbal constituents.

Complex verbs with prepositional constituents

[25] Complex verbs items in (3c) are decomposed here

\begin{tabular}{|c|c|c|}
\hline Verb & & Preposition \\
\hline $\begin{array}{l}\text { yẹ́ } \\
\text { (to honour) }\end{array}$ & + & $\begin{array}{l}\text { sí - to honour/ respect } \\
(-)\end{array}$ \\
\hline $\begin{array}{l}\text { rẹ̀ } \\
\text { (to cast fruits/ to blast) }\end{array}$ & $(-)$ & $\begin{array}{l}\text { sí }+ \text { ilê -to lower/degrade } \\
\text { ground }\end{array}$ \\
\hline $\begin{array}{l}\text { bẹ̀rẹ̀ } \\
\text { (to bend/start) }\end{array}$ & + & $\begin{array}{l}\text { sí - to start } \\
(-)\end{array}$ \\
\hline $\begin{array}{l}\text { dé } \\
\text { (to come) }\end{array}$ & + & $\begin{array}{l}\text { sí -(to befall } \\
(-)\end{array}$ \\
\hline
\end{tabular}

Complex verbs with prepositional constituents. $10.6 \%$ of the understudied verbs fall into this category.

Complex verbs in Yorùbá are divided into three:

- Syntactically inseparable complex verbs

- Syntactically separable complex verbs

- Syntactically multi-phased complex verbs i.e verbs whose separability depend on the sentence structure.

The examples below illustrate these categorization

Syntactically inseparable complex verbs include amongst others verbs like, fẹ́ràn (to love), gbàgbé (to forget), sọrọ̀ (to speak), fọhùn (to speak) 

[26] fẹ́+ràn
òun àti ìyá mi fệràn ara wọn
( himself and my mother love each other)
[27] gbà+gbé
Olódùmarè náà kò ní gbàgbé òun
(Olódùmarè would not also forget him/her)
[28] sọ+ọrọ̀
ó sọ̀rò $n$ kò rẹrìn-ín
(He/she was speaking but I didn't laugh)
[29] fọhùn
Láijẹ́ pé mo fohùn sí i, kò lè wá
( He wouldn't come without me beckoning on him)
[30] kọrin

$$
\text { Mòn kọrin }
$$$$
\text { (I am singing) }
$$

Syntactically separable complex verbs include the following: bájà (to fight with), bálà (to continue), àilówọ́ (to hinder), sọlórúko (to name), wòsàn (to heal).
[31] dí+lọ́wọ́
$n$ kò fẹ́ kí ènìyàn dí mi lộọ́ rárá
(I do not want anyone to hinder me at all)
[32] sọ+ lórúko
kí wọ́n mába sọ olúwarẹ lórúko
(so that they do not blacklist one)
[33] bá+jà
ẹni tí ó bá Àgbákò jà nínú igbó Irúnmọẹ
(the person that fought with Àgbákò in igbó Irúnmolè)
[34] bá+lo
máa bá òrọ̀ rẹ lọ
(continue talking)
[35] wò +sàn
bàbá mi wo sòbìyà rẹ̀ sàn
(My father healed his Guinea Worm).

Syntactically multi-phased complex verbs verb include the following the following verbs: bínú (to be angry), bàjẹ́ (to spoil/destroy), rántí (to remember/be reminded of), ránsí (send to)

[36] (i) bínú mọ hùwà bí ẹni pé kí ó bínú lọ (inseparable)

(He was acting as though I should get angry)

(ii) inú bí mi gidigidi (separable)

I was very angry.

[37] (i) ránsí

wọ́n ránsí mi láti pa mí

(inseparable)

(He was sent to kill me)

Mo ní iṣẹ láti rán sí àwọn omo aráyé (separable)

(Ihave a message to send you to the inhabitant of the world)

[38] (i) bàjẹ́

Àwọn ògùn mi náà bàjẹ́ pẹ̀lú

(inseparable)

My charms were equally destryoed

Ó ba Àkèrègbè lórúkojẹ́

(separable)

He tarnished Àkèrègbè's name

[39] (i) fisí

Mo fisí ara ikọ̀wé mi

(inseparable)

I placed it beside my writing pad

Olódùmarè fi bọtà sí búrẹdì fún mi

(separable)

Olódùmarè buttered my bread 
Like simple verbs, complex verbs in Yorùbá do not follow a special pattern in their past tense formation. The particle - ti- is often written in front of the verb to denote that the event is in the past.

[40] péjọ (to assemble) Àwọn ẹranko àti ẹbọra ti péjọ ní ojọ́ náà

(The animals and the demons were gathered this particular day)

[41] gbéwọ ( to put on) Wọ́n ti gbé agbára wọ.

(They have been empowered)

\section{MORPHO-SYNTACTIC ROLES OF COMPLEX VERBS IN BOTH GERMAN AND IN YORÙBÁ}

The morpho-syntactic roles of complex verbs in both languages are summarised by highlighting the morpho-syntactic differences and similarities of complex verb in both German and Yorùbá.

\subsection{Morpho-Syntactic Similarities of the Corpus}

Going through the morpho-syntactic structures and functions of the complex verbs in the two languages ,the following observations are noted .

\subsection{The Morpho-syntactic similarities}

- Simple verbs in both German and Yorùbá function as the base verbs for complex verb formation.

- German seperable complex verbs i.e particle verbs are both morphologically an syntactically separable, this also is the case for separable complex verbs in Yorùbá.

- Majority of complex verbs in both languages could be decomposed into two constituent, while those with three or four constituents are in the minority.

- Nominal and prepositional constituent are added to simple verbs to form complex verbs in both languages.

\subsection{Morpho-syntactic differences}

- While German complex verbs are product of derivational word process, complex verbs in Yorùbá are compositional constituents.

- Complex verbs in German are majorly formed by adding prepositional verbal particle while nominal constituent are in the majority with Yorùbá.

- While complex separable verbs in German are syntactically separable, multi-phased complex verbs are both syntactically separable and inseparable depending on the sentence structures.

- Complex verbs in German form their past tense by addition of a -ge- inbetween the particle and the verb while complex verbs in Yorùbá only take a -ti-before the verb.

- While contractions occur between verbs and it constituents in Yorùbá, such cases are absent with complex verbs in German.

\section{CONCLuSion}

Obsevably,one can draw the conclusion that the similarities identified as been between complex verbs in German and in Yorùbá languages validate the theory of language universals, and that languages have their distinctive features.The overall inference from the scenerio therefore, is that since no two languages are the same,linguists, translators interpreters and bilinguals should identify those differences and exploit them as areas to be underscored and be emphazised for pedagogical reasons .It is also contented that blowing those areas of differences/similariries will rightly situate the students to start learning the language concepts from known to unknown in order to ultimately effect desirable learning outcomes.

\section{REFERENCES}

[1] Adewole ,L.O.(1997), Head in Yorùbá Derived Nouns ( Manuscripts)

[2] Asiwaju, Micheal. (1967 ): Lehrbuch Der Yorùbá - Sprache. Leipzig: Verlag Enzyklopaedie.

[3] Awóbùlúyì, Qládélé (2008): Èkó İṣẹdá Òrọ̣ Yorùbá. Àkúrẹ́: Montem Paperbacks

[4] Dehe, Nicole (2015):"Particle Verb in the Germanic". An International Handbook of the Languages of Europe.Vol. 1 S. 611-625 
[5] Duden (2000): Die Deutsche Rechtsschreibung. Bibliographisches Institut\& E. A Brockhaus AG, Mannheim.

[6] Ogunwale, 1997:

[7] Fagunwa,D.O.(1949),Igbó Olódùmarè. Lagos.Nelson Nigeria limited.

[8] Fliescher

[9] Duden Grammatik Hamburg( 2009,)

[10] Müller Stefan, Syntax or morphology: German particle verbs revisited ,Explorations in Verb-Particle Constructions, Berlin 20

[11] Madugu, George (1985): “Complex Verbs in Yorùbá and Nupe”. Studies in African Linguistics, Vo.1. 16 (3), S. 295-321.

[12] Markus, Steinbach et al (2007):Schnittstellen der grammatischen Linguistik. Stuttgart: J. B. Metzler Verlag.

[13] Müller, Stefan (2002): Syntax or morphology: German Particle Verbs Revisited,Explorationsin VerbParticle Constructions. Berlin: Mouton de Gruyter.

[14] Ogunwale J.A.(1997), Some Syntactic Expositions of the Loci of Ambiguities in Yorùbá. Olota: Journal of African Studies , Ondo State University, Ado -Ekiti.

[15] Ògúnwálé, J.A (2005), "Problem of Lexical Decomposition: The Case of Yorùbá Complex Verbs". Normadic Journal of African Studies, Vol. 14 (3), S.318-333.

[16] Ogunwale,J.A.( 2007), Headhood in Yorùbá Compund Nominals

[17] Ogunwale,J.A (2012), Reduplication as Coppied Constituents in Yorùbá Lexical Morphology.

[18] Ogunwale J.A (2015), Problems and Prospect”.Studies of Tribes and Tribals, Vol.2 (2) S. 97-104.

[19] Robert,Lado

[20] Smieckova

[21] Sproat, Richard. "Language.” Language, vol. 70, no. 2, 1994, pp. 361-365.

[22] Steinback, Markus, et.al(2007), ${ }^{1}$ Schnittstellen der grammatischen Linguistik. Stuttgart S. 59

[23] In Steina 'bach et al a.a.O... S59 Stuttgart (2007) Wellman

[24] Willeke, Felix (2006):Die morphologische Integration englischer Verben im Deutschen unter besonderer Berücksichtigung von Partikelverben. Magisterarbeit. Humbolt Universität zu Berlin (unpublished).

Citation: Deborah Adeyeye, Ogunwale Abiodun. The Verbo -Nominal Structures in German and Yorùbá Languages: Parallels and Contrasts. "International Journal on Studies in English Language and Literature (IJSELL), vol 7, no. 10, 2019, pp. 41-53. doi: http://dx.doi.org/10.20431/2347-3134.0710006.

Copyright: (C) 2019 Authors. This is an open-access article distributed under the terms of the Creative Commons Attribution License, which permits unrestricted use, distribution, and reproduction in any medium, provided the original author and source are credited. 